\title{
Antioxidant activities and chemical composition of various crude extracts of Lepidagathis keralensis
}

\author{
Leena Palakkal ${ }^{*}$, N. H. Zeinul Hukuman, Jisha Mullappally \\ Department of Post Gradaute Studies and Research in Chemistry, Sir Syed College, Taliparamba, Kannur, Kerala, India.
}

\section{ARTICLE INFO}

Article history:

Received on: 03/05/2017

Accepted on: 15/06/2017

Available online: 30/06/2017

Key words:

Lepidagathis keralensis, antioxidant activity, phenolics, flavonoids, GCMS.

\begin{abstract}
Lepidagathis keralensis (Acanthaceae), a plant mainly used as a preventive medicine against malnutrition was studied for the evaluation of in vitro antioxidant activity. Petroleum ether, acetone, methanol and aqueous extract of the stem and leaves of the plant were analyzed. The Total Phenolic Content (TPC) and Total Flavonoid Content (TFC) were quantitatively estimated for correlation studies. DPPH radical scavenging assay, Reducing power assay and Phosphomolybdenum method were employed for the evaluation of antioxidant activity. Chemical components of the extracts showing higher antioxidant properties were subjected to Gas chromatography-mass spectrometry (GC-MS) analysis. Potent antioxidant activities were shown by the methanol extract of leaf and acetone extract of the stem in all the assays, with the methanol extract of leaf showing highest DPPH scavenging activity(94.78\%), reducing power(1.226 ) and total antioxidant activity $(656.89 \pm 1.68 \mathrm{mg} / \mathrm{g} \mathrm{AAE})$. Highest TPC and TFC were obtained for the methanol extract of leaf

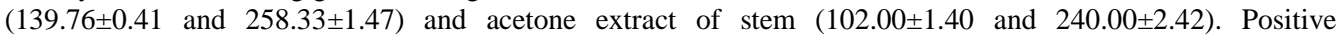
correlations were obtained for TPC and TFC with the observed antioxidant activity. GC-MS analysis of the extracts revealed the presence of 13 phytocomponents in the methanol extract of leaf. Cyclopentaneundecanoic acid methyl ester (27.4\%), Benzene, (ethenyloxy)-(17.3\%), n-Hexadecanoic acid (palmitic acid) (13.93\%) and 10 -Undecynoic acid, methyl ester (11.67\%) were the major components identified in the extract. 25 components were identified in the acetone extract of stem with Cyclopentaneundecanoic acid (29.6\%), 1,6-Octadiene,3,7dimethyl-(17.17\%), 10-Undecyn-1-ol(9.54\%) and 3-Hydroxy-4-methoxybenzoic acid(6.79\%) as the major components. The study confirms that the plant is rich source of natural antioxidants.
\end{abstract}

\section{INTRODUCTION}

Antioxidants are compounds that may protect the cells from oxidative damage caused by free radicals (Pavithra et al., 2013; Farida et al., 2014). Living organisms generate free radicals during metabolism of aerobic cells (Kandasamy and Aradhya, 2014). These free radicals lead to various chronic diseases such as atherosclerosis, cardio vascular diseases, cancer, ageing, diabetes, gastric ulcer and DNA damage (Shanta et al., 2013; Singh et al., 2013). Even though the human body possess antioxidant defense mechanisms, under certain conditions it may be inadequate and hence dietary intake of antioxidants are recommended (Padmanabhan and Jangle, 2012).

\footnotetext{
* Corresponding Author

Leena Palakkal, Department of Post Gradaute Studies and Research in Chemistry, Sir Syed College, Taliparamba, Kannur, Kerala, India.

Email: leenasajithp@gmail.com
}

Recent research findings have confirmed that synthetic antioxidants such as butylated hydroxyanisole (BHA) and butylated hydroxytoluene (BHT), which are used in food industry, are associated with several toxic effects. Hence there is an increased attention towards plant based natural antioxidants (Hemalatha et al., 2016; Meechai et al., 2016). There exists an inverse relation between human diseases and dietary intake of food rich in antioxidants (Yildirim et al., 2001). The antioxidant potential of the plant is mainly considered to be due to the presence of phenolics and flavonoids (Galvez, 2015). Lepidagathis keralensis, an endemic plant of Kerala belonging to the family Acanthaceae is found near seacoast in exposed lateritic rocks. It is a rigid prostrate under shrub with woody rootstock (Madhusoodanan and Singh, 1992).

The plant possesses several medicinal properties. It is used by the paniya tribes for treating bronchial asthma in children (Divakar et al., 2010). 
The gruel prepared by cooking the spines of the plant with rice is used as a preventive medicine for malnutrition, malabsorption and digestive disorders. Decoction of the whole plant is recommended for kidney stone and albumin in urine. The plant is also used as a blood purifier and increases blood. Whole plant decoction with cumin seeds is given for chest pain (Prasad S., 2012). The antimicrobial efficiency of the petroleum ether extracts of the plant were studied previously in our laboratory. The chemical constituents in the extract were also determined by GCMS analysis (Leena et al., 2016).

Lepidagathis keralensis is a less explored plant for chemical studies and antioxidant studies in this plant are not known to be reported so far. Thus this study deals with the evaluation of antioxidant potency of the different extracts of the leaves and stem of the plant. Correlations of the observed activity were done with total phenolic content (TPC) and total flavonoid content (TFC). The extracts showing higher antioxidant efficiency were further examined by gas chromatography-mass spectrometry (GC-MS) to identify the bioactive constituents present.

\section{MATERIALS AND METHODS}

\section{Collection and preparation of plant extracts}

The plant, Lepidagathis keralensis was collected from the lateritic rocks of Madayipara, Kerala during September 2015 and was authenticated from the Department of Botany, Govt. Brennen College, Thalassery, Kerala. A voucher specimen (TALI 1174) was deposited at the herbarium, Dept. of PG studies and Research in Botany Sir Syed College, Taliparamba, Kerala. The leaves and stem of the plant were separated, washed well, and dried in shade for three weeks. The shade dried plant parts were then powdered well and extracted with petroleum ether, acetone and methanol sequentially in a soxhlet apparatus. The aqueous extracts were prepared by cold maceration method in a mechanical shaker. The extracts were concentrated under reduced pressure and stored in refrigerator for further studies.

\section{In vitro antioxidant assays}

The antioxidant assays of the petroleum ether, acetone, methanol and aqueous extracts of the stem and leaves of the plant were carried out by the following methods:

\section{DPPH radical scavenging assay}

Based on the scavenging ability of the stable 1, 1diphenyl-2- picryl hydrazyl (DPPH) free radical, the antioxidant activity of the extracts were determined by the method described by Dasgupta et al.(2004).0.1 $\mathrm{ml}$ of Plant extracts ( $200,300,400,500$ and $600 \mu \mathrm{g} / \mathrm{ml}$ in methanol) was added to $3 \mathrm{ml}$ of a $0.004 \%$ of DPPH solution in methanol. After $30 \mathrm{~min}$, absorbance was determined at $517 \mathrm{~nm}$ against methanol as blank. The percentage of inhibition activity was calculated as follows: Percentage inhibition of DPPH activity $=[($ Ac-As $) / A c] * 100$

Ac is the absorbance of the control (DPPH solution) and As is the absorbance of the extract/standard. The inhibition curves were prepared and $\mathrm{IC}_{50}$ values calculated. Ascorbic acid was used as the standard.

\section{Reducing power assay}

The reducing power of the extracts was assayed according to the method described by Alam et al (2013). Different concentrations of extracts $(50,100,150,200$ and $250 \mu \mathrm{g} / \mathrm{ml})$ in $1 \mathrm{ml}$ of distilled water were mixed with $2.5 \mathrm{ml}$ of $0.2 \mathrm{M}$ phosphate buffer ( $\mathrm{pH}$ 6.6). $2.5 \mathrm{ml}$ of $1 \% \mathrm{~K}_{3} \mathrm{Fe}(\mathrm{CN})_{6}$ was added to this solution and the resulting mixture was incubated at $50{ }^{\circ} \mathrm{C}$ for $20 \mathrm{~min}$. $2.5 \mathrm{ml}$ of $10 \%$ Trichloro acetic acid was then added to the solution and mixture centrifuged at $3000 \mathrm{rpm}$ for $10 \mathrm{~min} .2 .5 \mathrm{ml}$ of the upper layer was collected and mixed with $2.5 \mathrm{ml}$ of distilled water and $0.5 \mathrm{ml}$ of $0.1 \% \mathrm{FeCl}_{3}$ was then added. Absorbance of the mixture was then measured at 700 $\mathrm{nm}$. Increased absorbance of the reaction mixture indicates increased antioxidant ability. Ascorbic acid was used as the standard.

\section{Total antioxidant activity}

The total antioxidant activity of the sample was analyzed by Phosphomolybdenum method (Kumaran and Karunakaran, 2007). $0.3 \mathrm{ml}$ of the sample was taken and mixed with $3 \mathrm{ml}$ of reagent solution $(0.6 \mathrm{M}$ sulfuric acid, $28 \mathrm{mM}$ sodium phosphate and $4 \mathrm{mM}$ ammonium molybdate). The solution was incubated at $95^{\circ} \mathrm{C}$ for $90 \mathrm{~min}$. and cooled to room temperature. The absorbance of the solution was measured at $695 \mathrm{~nm}$ using Labtronics single beam UV-Visible LT-290 spectrophotometer against methanol as blank. Standard calibration curve was prepared using ascorbic acid and the total antioxidant activity was expressed as ascorbic acid equivalents.

\section{Determination of total phenolic content}

The total phenolic content (TPC) of plant extracts were determined using Folin-Ciocalteu reagent (Yu et al., 2002). $100 \mu \mathrm{l}$ plant extract (prepared by dissolving $100 \mathrm{mg}$ extract in $100 \mathrm{ml}$ distilled water) was mixed with $500 \mu$ of the Folin-Ciocalteu reagent and $1.5 \mathrm{ml}$ of $20 \%$ sodium carbonate. The mixture was shaken thoroughly and made up to $10 \mathrm{ml}$ using distilled water. After 2 hours, the absorbance of the solution was determined at $765 \mathrm{~nm}$ using Labtronics single beam UV-Visible LT-290 spectrophotometer. From the data obtained, TPC was determined using standard calibration curve of Gallic acid and results were expressed as Gallic acid equivalents. Triplicate measurements were taken for all extracts.

\section{Determination of total flavonoid content}

The total flavonoid content (TFC) of each plant extract was estimated by Aluminium chloride colorimetric method (Deori et al., 2014). Based on this method, $1 \mathrm{ml}$ of the sample was dissolved in $4 \mathrm{ml}$ of distilled water. $0.3 \mathrm{ml}$ of a $5 \% \mathrm{NaNO}_{2}$ solution was then added. After $5 \mathrm{~min}, 0.3 \mathrm{ml}$ of $10 \% \mathrm{AlCl}_{3}$ solution was added and allowed to stand for $6 \mathrm{~min} .2 \mathrm{ml}$ of $1 \mathrm{M}$ $\mathrm{NaOH}$ solution was then added to the mixture. The solution was diluted to $10 \mathrm{ml}$, thoroughly mixed and allowed to stand for 
another $15 \mathrm{~min}$. The absorbance of the mixture was then determined at $510 \mathrm{~nm}$ using Labtronics single beam UV-Visible LT-290 spectrophotometer. Water was used as blank. TFC was determined using standard calibration curve of Rutin and results were expressed as Rutin equivalents. Triplicate measurements were recorded for all extracts.

\section{Gas chromatography-mass spectroscopic analysis}

GC-MS analyses of the extracts showing better antioxidant activity were carried out from Sir Syed College, Taliparamba, Kerala. The analysis were done using a Thermoscientific Trace 1300 Gas chromatograph equipped with ISQ- QD Mass spectrometer with TG-5MS non polar column (30 $\mathrm{m} \times 0.25 \mathrm{~mm}$ ID $\times 0.25 \mu \mathrm{m}$ df).GC-MS detection were done with an electron ionization system with an ionizing energy of $70 \mathrm{ev}$. Helium gas $(99.99 \%)$ was used as the carrier gas at constant flow rate $1 \mathrm{ml} / \mathrm{min}$. Injection volume was $1 \mu \mathrm{l}$ with split ratio $1: 8$. Injection port temperature of $280^{\circ} \mathrm{C}$ and an ion-source temperature of $200^{\circ} \mathrm{C}$ were set. The analysis of the extracts were done by programming the oven temperature initially at $70^{\circ} \mathrm{C}$ (kept isothermal for $3 \mathrm{~min}$.) and then increased to $180^{\circ} \mathrm{C}$ at a rate of $6^{0} \mathrm{C} / \mathrm{min}$. with a hold time of $3 \mathrm{~min}$. The temperature was then increased at a rate of $5^{\circ} \mathrm{C} / \mathrm{min}$. to $240^{\circ} \mathrm{C}$ and held isothermally for $5 \mathrm{~min}$. Total GC running time was $40 \mathrm{~min}$. The components in the extracts were identified based on the comparison of mass spectra of the unknown component with those of known components stored in the NIST library.

\section{Statistical Analysis}

Measurements were recorded in triplicates for all the analysis. Results were calculated as the mean $(n=3) \pm$ SD (standard deviation) for each sample. One-way ANOVA followed by student's t- test was performed using GraphPad Prism version 7.02 for Windows (GraphPad Software, La Jolla California, USA). $\mathrm{p}<0.05$ were considered significant. The Pearson correlation coefficient (r) was used to study correlations of phenolics and flavonoids with observed antioxidant activity. $\mathrm{IC}_{50}$ values were determined using nonlinear regression method.

\section{RESULTS AND DISCUSSION}

\section{Antioxidant activity \\ DPPH assay}

DPPH is a stable free radical, turning color from red to yellow when scavenged. Antioxidants reduce DPPH by donating a proton and thereby decreasing the absorbance of the solution in methanol at $517 \mathrm{~nm}$. The scavenging potential of the extracts is therefore determined by the discoloration of DPPH in methanol. A decrease in absorbance value thus indicates an increase in antioxidant activity. (Thambiraj and Paulsamy, 2012) The radical scavenging activity of the different extracts of leaves and stem are depicted in Figure 1 and 2 respectively. Among the different extracts tested, the methanol extract of leaf showed a maximum inhibition activity of $94.78 \%$ which was comparable with that of standard ascorbic acid (96.38\%). The extract showed an $\mathrm{IC}_{50}$ value of $122.46 \pm 0.85$. (Table 1) The analysis of stem extracts revealed that the acetone extract of stem was more potential antioxidant showing maximum inhibition activity of $86.46 \%$. The results show that the plant possesses potential free radical scavenging activities.

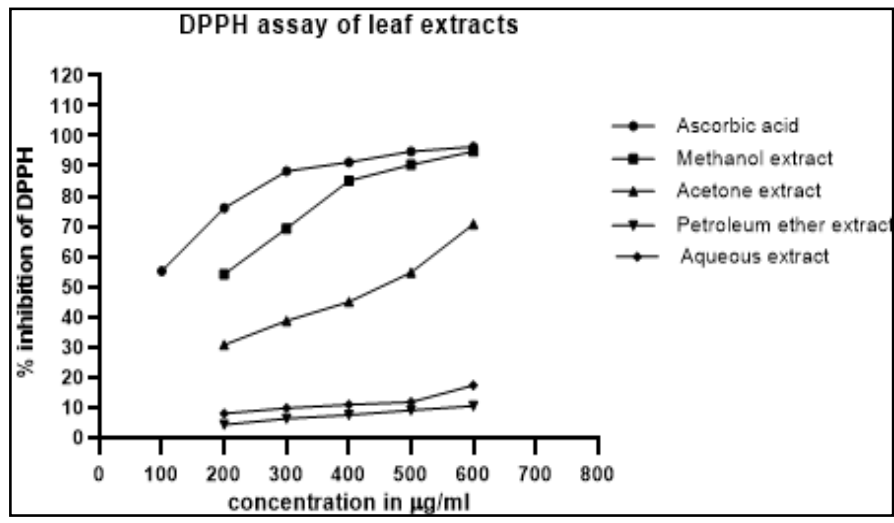

Fig. 1: DPPH radical scavenging activity of the extracts of Lepidagathis keralensis leaf and standard ascorbic acid. The values are expressed as mean of three replicate values.

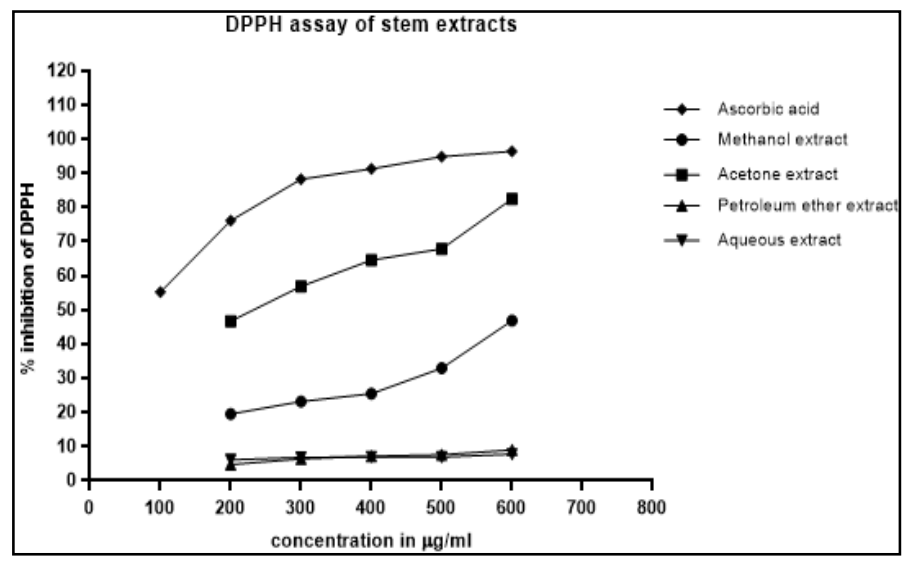

Fig. 2: DPPH radical scavenging activity of the extracts of Lepidagathis keralensis stem and standard ascorbic acid. The values are expressed as mean of three replicate values.

Table 1: $\mathrm{IC}_{50}$ values obtained for DPPH assay of extracts of leaves and stem of Lepidagathis keralensis and standard ascorbic acid.

\begin{tabular}{ccc}
\hline \multirow{2}{*}{ Extract } & \multicolumn{2}{c}{$\mathbf{I C}_{\mathbf{5 0}}$} \\
\cline { 2 - 3 } & Leaf extract & Stem extract \\
\hline Petroleum ether & $\mathrm{ns} *$ & $\mathrm{~ns} *$ \\
Acetone & $449.27 \pm 1.23$ & $231.87 \pm 1.69$ \\
Methanol & $122.46 \pm 0.85$ & $618.37 \pm 1.12$ \\
Aqueous & $875 \pm 1.04$ & $\mathrm{~ns} *$ \\
Ascorbic acid & $76.18 \pm 0.68$ & $76.18 \pm 0.68$ \\
\hline ns - not significant values are expressed as mean \pm SD of three replicate
\end{tabular}
values.

\section{Reducing power}

This method is based on the principle that antioxidant compounds reduces $\mathrm{Fe}^{3+} /$ ferricyanide complex to the ferrous form, changing the yellow color of the solution to shades of green and blue. The colored complex formed (Perl's Prussian blue), shows 
an absorbance at 700nm. Thus an increase in absorbance indicates an increase in antioxidant potential (Ferreira et al., 2007). All the extracts analyzed, showed an increase in absorbance with increase in concentration which suggests that the plant is a good antioxidant. The results are depicted in Figure 3 and 4. The methanol extract of leaf showed the highest absorbance (1.226) which was close to the absorbance shown by standard ascorbic acid (1.462). Among the extracts of stem, the acetone extract showed highest antioxidant potential with an absorbance value of 0.824 .

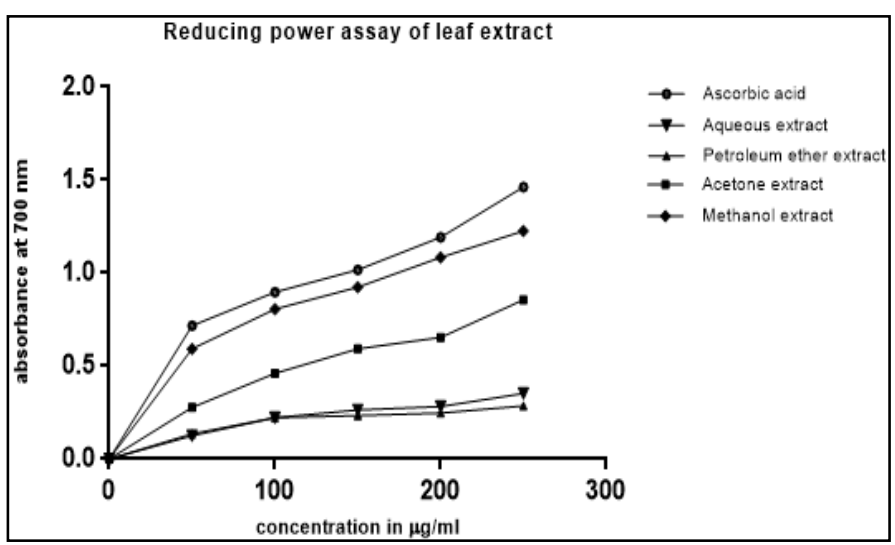

Fig. 3: Reducing power ( absorbance at 700nm) of extracts of Lepidagathis keralensis leaf and standard ascorbic acid at different concentrations. The values are expressed as mean of three replicate values.

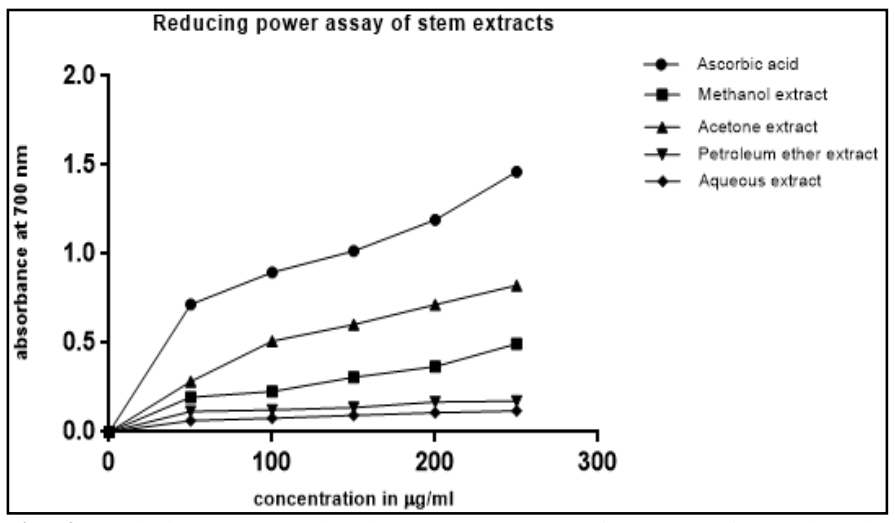

Fig. 4: Reducing power ( absorbance at 700nm) of extracts of Lepidagathis keralensis stem and standard ascorbic acid at different concentrations. The values are expressed as mean of three replicate values.

\section{Total antioxidant activity}

The total antioxidant activities of the extracts as determined by Phosphomolybdenum method are shown in Table 2. The method is based on the reduction of Mo (VI) to Mo (V) to form a green phosphate Mo (V) complex at acidic $\mathrm{pH}$ by the analyzed sample. Among the extracts analyzed, highest total antioxidant activity was shown by the methanol extract of leaf (656.89 \pm 1.68$)$, followed by the acetone extract of stem
(532.00 \pm 2.0$)$. A comparative evaluation of total antioxidant activities are depicted in Figure 5.

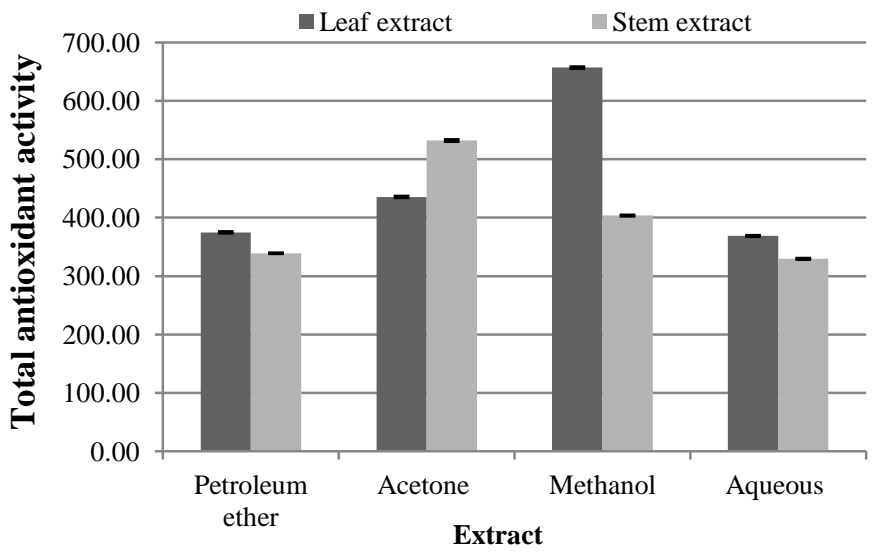

Fig. 5: Total antioxidant activity (mg/g AAE) determined by phosphomolybdenum method of different extracts of leaves and stem of Lepidagathis keralensis. The values are expressed as mean $\pm \mathrm{SD}$ of three replicate values.

Table 2: Total antioxidant capacity in mg/g AAE of extracts of leaves and stem of Lepidagathis keralensis

\begin{tabular}{ccc}
\hline \multirow{2}{*}{ Extract } & \multicolumn{2}{c}{ Total antioxidant activity in mg/g AAE } \\
\cline { 2 - 3 } & Leaf extract & Stem extract \\
\hline Petroleum ether & $374.89 \pm 1.68$ & $339.11 \pm 1.02$ \\
Acetone & $435.56 \pm 1.64$ & $532.00 \pm 2.0$ \\
Methanol & $656.89 \pm 1.68$ & $403.56 \pm 1.33$ \\
Aqueous & $368.67 \pm 1.33$ & $329.56 \pm 1.39$ \\
\hline
\end{tabular}

values are expressed as mean \pm SD of three replicate values.

AAE-Ascorbic Acid Equivalent

\section{Total Phenolic Content (TPC) and Total Flavonoid Content (TFC)}

Presence of phenolics and flavonoids are considered to be the main reason for antioxidant capacity of a plant. Polyphenolic compounds show antioxidant activity owing to their redox properties, which provide them the ability to scavenge free radicals by $\mathrm{H}$ - atom or e- transfer process, inhibit redox active enzymes, decompose peroxides, quench singlet and triplet oxygen, chelate metal catalysts etc. (Valentova et al., 2003; Gil and Couto, 2013). In the present study, TPC and TFC were quantitatively estimated by Folin-Ciocalteu method and Aluminium chloride method respectively.

The results obtained are given in Table 3.It was observed that the methanol extract of leaf contained highest amount of TPC (139.76 $\pm 0.41 \mathrm{mg}$ GAE/g) and TFC (258.33 $\pm 1.47 \mathrm{mg} \mathrm{RE} / \mathrm{g})$. Among the stem extracts analyzed, the acetone extract showed maximum amount of TPC $(102.00 \pm 1.40 \mathrm{mg}$ GAE/g) and TFC $(240.00 \pm 2.42 \mathrm{mg} \mathrm{RE} / \mathrm{g})$. The results obtained were in accordance with the studies that plants with higher TPC and TFC show higher antioxidant potential (Lima et al., 2014). Even though the petroleum ether extract of stem showed a high TFC content (138.33 $\pm 1.92 \mathrm{mg} \mathrm{RE} / \mathrm{g})$, the observed antioxidant activities for the extract were not so high. This might be due to the presence of large number of glycosidic moieties associated with flavonol 
glycosides. Antioxidant activities of flavonoids are influenced by the position, structure and total number of sugar units (Kumar and Pandey, 2013).

Table 3: Quantitative analysis of phenolics and flavonoids in the extracts of leaves and stem of Lepidagathis keralensis

\begin{tabular}{cccc}
\hline \multirow{4}{*}{ Extract } & TPC & TFC \\
& mg GAE/g & mg RE/g \\
\hline \multirow{4}{*}{ Stem } & Petroleum ether & $14.19 \pm 0.25$ & $3.33 \pm 0.96$ \\
& Acetone & $104.73 \pm 0.94$ & $91.67 \pm 2.42$ \\
& Methanol & $139.76 \pm 0.41$ & $258.33 \pm 1.47$ \\
& Aqueous & $9.81 \pm 0.27$ & $6.66 \pm 1.47$ \\
\hline & Petroleum ether & $4.79 \pm 0.14$ & $138.33 \pm 1.92$ \\
& Acetone & $102.00 \pm 1.40$ & $240.00 \pm 2.42$ \\
& Methanol & $66.98 \pm 0.42$ & $61.67 \pm 2.00$ \\
& Aqueous & $3.56 \pm 0.26$ & $8.33 \pm 2.42$ \\
\hline
\end{tabular}

values are expressed as mean $\pm \mathrm{SD}$ of three replicate values.

TPC- Total Phenolic Content expressed as mg/g Gallic Acid Equivalents.

TFC- Total Flavonoid Content expressed as mg/g Rutin Equivalents.

Table 4: Pearson correlation coefficient (r) values for correlation between TPC, TFC and antioxidant activities of Lepidagathis keralensis:

\begin{tabular}{ccccc}
\hline & & DPPH & Reducing power & $\begin{array}{c}\text { Total antioxidant } \\
\text { activity }\end{array}$ \\
\hline \multirow{2}{*}{ Leaf } & TPC & $0.995^{*}$ & $0.988^{*}$ & 0.873 \\
& TFC & 0.933 & $0.966^{*}$ & $0.992^{*}$ \\
\hline \multirow{2}{*}{ Stem } & TPC & $0.993^{*}$ & $0.990^{*}$ & $0.955^{*}$ \\
& TFC & 0.709 & 0.738 & 0.796 \\
\hline
\end{tabular}

* Significant correlation at $\mathrm{p}<0.05$ levels

The results of Pearson correlation analysis ( $\mathrm{r}$ value) of the observed TPC and TFC with the antioxidant activities are tabulated in Table 4. Strong positive correlations were obtained between TPC of leaf extracts and antioxidant activity by DPPH assay $(r=0.995)$. Results of reducing power method also showed good correlation with TPC $(r=0.988)$ and TFC $(r=0.966)$ of leaf extracts. The total antioxidant activity of the leaf was found to be in good correlation with TFC $(r=0.992)$, while no significant correlations were found with TPC. Antioxidant activities of the stem extracts showed significant correlation $(p<0.05)$ with TPC for all the assays, while TFC showed less correlation.

\section{GC-MS analysis}

Highest antioxidant efficiencies were shown by the methanol extract of leaf and acetone extract of stem. Hence these extracts were subjected to GC-MS analysis, which revealed the presence of 13 phytocomponents in the methanol extract of leaf and 25 components in the acetone extract of stem (Table 5 and Table 6). Cyclopentaneundecanoic acid methyl ester (27.4\%), Benzene, (ethenyloxy)-(17.3\%), n-Hexadecanoic acid (palmitic acid) $(13.93 \%)$ and 10-Undecynoic acid, methyl ester (11.67\%) were the major components identified in the leaf extract. Of the several components identified, many possess varied potential bioactivities. Components identified to possess antioxidant properties were Benzene, (ethenyloxy)-, 2-Methoxy-4-vinylphenol and n-Hexadecanoic acid (Flora and Rani, 2010; Gopalakrishnan and Vadivel, 2011; Vijayakumar and Sumathi, 2016). The major components identified in the acetone extract of stem were Cyclopentaneundecanoic acid (29.6\%), 1, 6-Octadiene, 3, 7dimethyl-(17.17\%), 10-Undecyn-1-ol (9.54\%) and 3-Hydroxy-4methoxybenzoic acid (6.79\%). Among the 25 components identified, 3-Hydroxy-4-methoxybenzoic acid, 2-Methoxy-4vinylphenol, vanillic acid and 2-Piperidinone, N-[4-bromo-nbutyl] - were found to possess antioxidant activities (Khadem and Marles, 2010; Kumar et al., 2011; Meenakshi et al., 2012; Hussein et al., 2016). The GC-MS chromatograms of the extracts are shown in Figure 6 and 7. Although no reported data are available on the GC-MS studies in this plant, n-Hexadecanoic acid, Vanillic acid, (E)-4-(3-Hydroxyprop-1-en-1-yl)-2-methoxyphenol and 1,6Octadiene,3,7-dimethyl were previously reported to be present in different plant extracts belonging to the family Acanthaceae(Kalaiselvan et al., 2012; Awan et al., 2014; Kumar et al., 2016 ). Several other phytocomponents identified in the extracts were found to possess antibacterial, antifungal, anticancer, anti inflammatory and diuretic properties (Kumari et al., 2012; Shettima et al., 2013). The study thus highlights the medicinal importance of the plant.

Table 5: Compounds identified in the methanolic extract of Lepidagathis keralensis leaf by GC-MS analysis.

\begin{tabular}{|c|c|c|c|c|c|}
\hline Sl. No. & RT & Name of the Compound & Molecular formula & Molecular weight & Peak area \% \\
\hline 1 & 5.28 & Tiglic acid & $\mathrm{C}_{5} \mathrm{H}_{8} \mathrm{O}_{2}$ & 100 & 0.43 \\
\hline 2 & 9.25 & Heptanoic acid, 6-oxo- & $\mathrm{C}_{7} \mathrm{H}_{12} \mathrm{O}_{3}$ & 144 & 3.48 \\
\hline 3 & 12.89 & Benzene, (ethenyloxy)- & $\mathrm{C}_{8} \mathrm{H}_{8} \mathrm{O}$ & 254 & 17.30 \\
\hline 4 & 13.14 & 4-Hexen-3-one, 4,5-dimethyl- & $\mathrm{C}_{8} \mathrm{H}_{14} \mathrm{O}$ & 126 & 5.4 \\
\hline 5 & 15.46 & 2-Methoxy-4-vinylphenol & $\mathrm{C}_{9} \mathrm{H}_{10} \mathrm{O}_{2}$ & 150 & 0.23 \\
\hline 6 & 25.30 & 2,3,4,5-Tetramethoxybenzaldehyde & $\mathrm{C}_{11} \mathrm{H}_{14} \mathrm{O}_{5}$ & 226 & 0.36 \\
\hline 7 & 29.42 & Cyclopentaneundecanoic acid, methyl ester & $\mathrm{C}_{17} \mathrm{H}_{32} \mathrm{O}_{2}$ & 268 & 27.4 \\
\hline 8 & 30.20 & n-Hexadecanoic acid(palmitic acid) & $\mathrm{C}_{16} \mathrm{H}_{32} \mathrm{O}_{2}$ & 256 & 13.93 \\
\hline 9 & 31.03 & 4,5-Dimethoxy-6-[2-nitroethenyl]-2H-1,3-benzodioxole & $\mathrm{C}_{11} \mathrm{H}_{11} \mathrm{NO}_{6}$ & 253 & 1.88 \\
\hline 10 & 31.70 & 10-Undecyn-1-ol & $\mathrm{C}_{11} \mathrm{H}_{20} \mathrm{O}$ & 168 & 8.61 \\
\hline 11 & 31.75 & 10-Undecynoic acid, methyl ester & $\mathrm{C}_{12} \mathrm{H}_{20} \mathrm{O}_{2}$ & 196 & 11.67 \\
\hline 12 & 31.84 & 9-Octadecen-12-ynoic acid, methyl ester & $\mathrm{C}_{19} \mathrm{H}_{32} \mathrm{O}_{2}$ & 292 & 1.82 \\
\hline 13 & 31.92 & Cyclopropanepentanoic acid, 2-undecyl-, methyl ester, trans- & $\mathrm{C}_{20} \mathrm{H}_{38} \mathrm{O}_{2}$ & 310 & 7.5 \\
\hline
\end{tabular}


Table 6: Compounds identified in the acetone extract of Lepidagathis keralensis stem by GC-MS analysis.

\begin{tabular}{|c|c|c|c|c|c|}
\hline Sl. no & RT & Name of the Compound & Molecular formula & Molecular weight & Peak area \% \\
\hline 1 & 3.78 & 2-Pentanone, 4-hydroxy-4-methyl- & $\mathrm{C}_{6} \mathrm{H}_{12} \mathrm{O}_{2}$ & 116 & 2.64 \\
\hline 2 & 5.60 & (R)-(-)-2,2-Dimethyl-1,3-dioxolane-4-methanol & $\mathrm{C}_{6} \mathrm{H}_{12} \mathrm{O}_{3}$ & 132 & 3.32 \\
\hline 3 & 6.22 & Ethanol, $2,2^{\prime}$-oxybis- & $\mathrm{C}_{4} \mathrm{H}_{10} \mathrm{O}_{3}$ & 106 & 0.47 \\
\hline 4 & 6.36 & (R)-(-)-2,2-Dimethyl-1,3-dioxolane-4-methanol/Solketal & $\mathrm{C}_{6} \mathrm{H}_{12} \mathrm{O}_{3}$ & 132 & 1.13 \\
\hline 5 & 7.22 & 2-Butanone, 4-hydroxy-3-methyl- & $\mathrm{C}_{5} \mathrm{H}_{10} \mathrm{O}_{2}$ & 102 & 1.54 \\
\hline 6 & 15.46 & 2-Methoxy-4-vinylphenol & $\mathrm{C}_{9} \mathrm{H}_{10} \mathrm{O}_{2}$ & 150 & 0.75 \\
\hline 7 & 17.68 & Benzaldehyde, 4-hydroxy-3-methoxy- & $\mathrm{C}_{8} \mathrm{H}_{8} \mathrm{O}_{3}$ & 152 & 1.12 \\
\hline 8 & 21.70 & 4-Methyloctanoic acid & $\mathrm{C}_{9} \mathrm{H}_{18} \mathrm{O}_{2}$ & 158 & 1.35 \\
\hline 9 & 21.92 & Vanillic acid & $\mathrm{C} 8 \mathrm{H} 8 \mathrm{O} 4$ & 168 & 3.71 \\
\hline 10 & 22.07 & 3-Hydroxy-4-methoxybenzoic acid & $\mathrm{C} 8 \mathrm{H} 8 \mathrm{O} 4$ & 168 & 6.79 \\
\hline 11 & 24.84 & 3,7-Cyclodecadien-1-one, 10-(1-methylethenyl)-, (E,E)- & $\mathrm{C}_{13} \mathrm{H}_{18} \mathrm{O}$ & 190 & 0.91 \\
\hline 12 & 25.67 & (E)-4-(3-Hydroxyprop-1-en-1-yl)-2-methoxyphenol & $\mathrm{C}_{10} \mathrm{H}_{12} \mathrm{O}_{3}$ & 180 & 5.55 \\
\hline 13 & 26.11 & 2,3-Epoxyhexanol & $\mathrm{C}_{6} \mathrm{H}_{12} \mathrm{O}_{2}$ & 116 & 1.80 \\
\hline 14 & 26.33 & (6,7-Dimethoxy-2H-1,3-benzodioxol-5-yl)methanol & $\mathrm{C}_{10} \mathrm{H}_{12} \mathrm{O}_{5}$ & 212 & 0.53 \\
\hline 15 & 27.65 & 1-Octadecyne & $\mathrm{C}_{18} \mathrm{H}_{34}$ & 250 & 2.86 \\
\hline 16 & 28.15 & 2-Decen-1-ol & $\mathrm{C}_{10} \mathrm{H}_{20} \mathrm{O}$ & 156 & 0.62 \\
\hline 17 & 28.52 & 1-Dodecyne & $\mathrm{C}_{12} \mathrm{H}_{22}$ & 166 & 0.32 \\
\hline 18 & 29.26 & 1,1-Dodecanediol, diacetate & $\mathrm{C}_{16} \mathrm{H}_{30} \mathrm{O}_{4}$ & 286 & 0.37 \\
\hline 19 & 30.37 & Cyclopentaneundecanoic acid & $\mathrm{C}_{16} \mathrm{H}_{30} \mathrm{O}_{2}$ & 254 & 29.60 \\
\hline 20 & 31.86 & (2S,3S)-(-)-3-Propyloxiranemethanol & $\mathrm{C}_{6} \mathrm{H}_{12} \mathrm{O}_{2}$ & 116 & 0.94 \\
\hline 21 & 32.49 & 2-Piperidinone, N-[4-bromo-n-butyl]- & $\mathrm{C}_{9} \mathrm{H}_{16} \mathrm{BrNO}$ & 233 & 0.41 \\
\hline 22 & 32.81 & 1,6-Octadiene,3,7-dimethyl (Dihydromyrcene) & $\mathrm{C}_{10} \mathrm{H}_{18}$ & 138 & 17.17 \\
\hline 23 & 32.87 & 10-Undecyn-1-ol & $\mathrm{C}_{11} \mathrm{H}_{20} \mathrm{O}$ & 168 & 9.54 \\
\hline 24 & 33.07 & 3-Ethylheptanoic acid & $\mathrm{C}_{9} \mathrm{H}_{18} \mathrm{O}_{2}$ & 158 & 2.77 \\
\hline 25 & 39.72 & 1-Heptatriacotanol & $\mathrm{C}_{37} \mathrm{H}_{76} \mathrm{O}$ & 536 & 1.99 \\
\hline
\end{tabular}

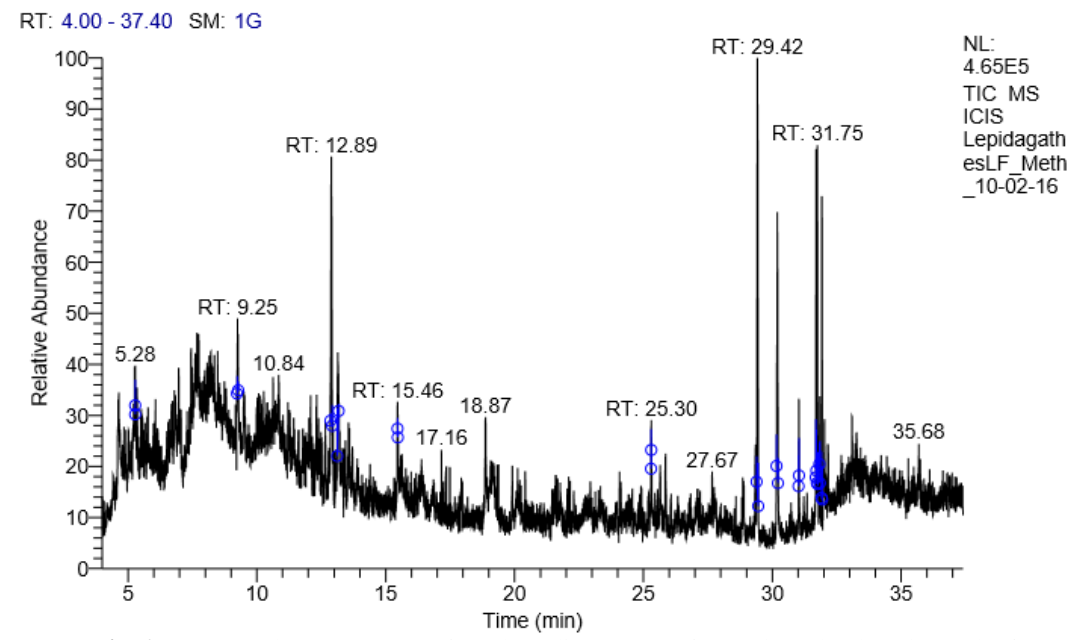

Fig.6: GC-MS chromatogram of methanolic extract of Lepidagathis keralensis leaf.

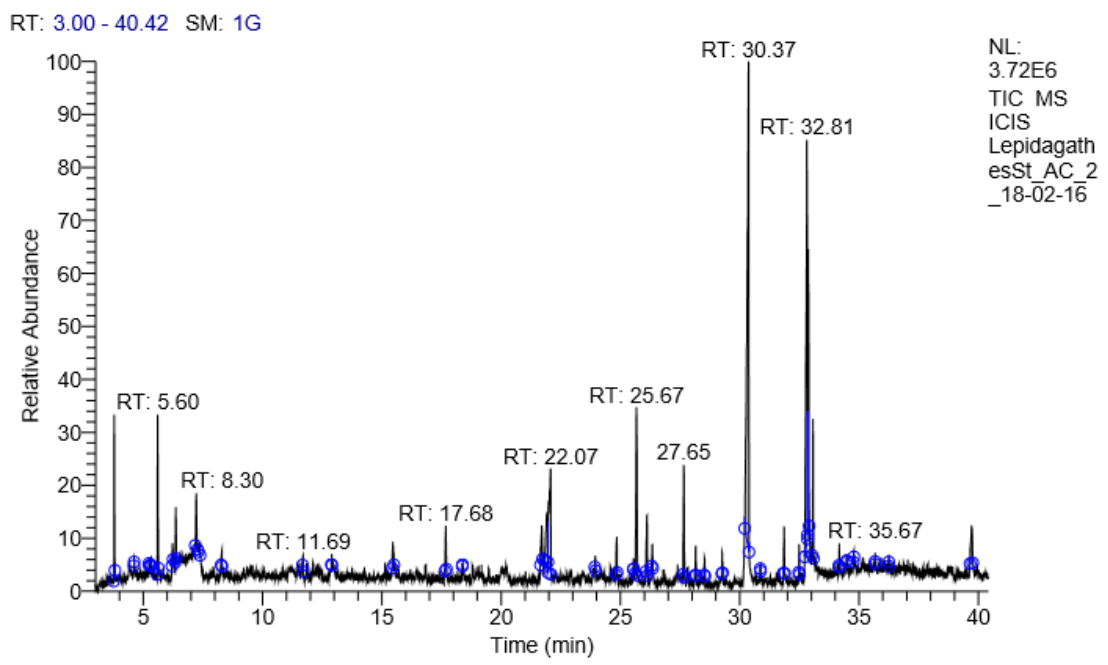

Fig.7: GC-MS chromatogram of acetone extract of Lepidagathis keralensis stem. 


\section{CONCLUSION}

The present study reveals that the methanol extract of leaf and acetone extract of stem of the plant, Lepidagathis keralensis possess good antioxidant activities. These activities can be attributed to the presence of high TFC and TPC in the extracts, which were confirmed by correlation studies. The extracts also showed the presence of various biologically active phytocomponents in GC-MS analysis. The presence of these phytocomponents also contributes to the observed medicinal property in addition to the antioxidant activity of the plant. The present study highlights the importance of the plant as a source of natural antioxidant. The plant can thus be further explored for isolation and characterization of bioactive components in the extracts.

\section{ABBREVIATIONS}

Gas Chromatography-Mass Spectrometry: GC-MS, Total Phenolic Content: TPC, Total Flavonoid Content: TFC, 1, 1diphenyl-2- picryl hydrazyl: DPPH, Gallic Acid Equivalents: GAE, Rutin Equivalents: RE.

\section{ACKNOWLEDGEMENTS}

The authors are also thankful to Sir Syed College, Kannur, India for providing necessary facilities.

Financial support and sponsorship: The corresponding author is grateful to UGC, India, for providing financial assistance by awarding research fellowship under Faculty Development Program (FDP).

Conflict of Interests: There are no conflicts of interest.

\section{REFERENCES}

Alam M.N., Bristi N.J., Rafiquzzaman M. Review on in vivo and in vitro methods evaluation of antioxidant activity. Saudi Pharm J. 2013; 21(2): 143-152.

Awan A.J., Ahmed C.B., Uzair M., Aslam M.S., Farooq U., Ishfaq K. Family Acanthaceae and genus Aphelandra : Ethno pharmacological and phytochemical review. Int J Pharm Pharm Sci. 2014; 6(10): 44-55.

Dasgupta N., De B. Antioxidant activity of Piper betle L. leaf extract in vitro. Food Chem. 2004; 88(2): 219-224.

Deori M., Boruah D.C., Devi D., Devi R. Antioxidant and antigenotoxic effects of pupae of the muga silkworm Antheraea assamensis. Food Biosci. 2014; 5:108-114.

Divakar M.C., Sandhya S., Vinod K.R., Razik A.P., Ranjimol K.K., Mohan S. Traditional knowledge and techniques of the Iritty hill tribals of Kannur district, Kerala. : A review. Int J Drug Formul Res. 2010; $1(1): 12-53$

Farida Y., Irpan K., Fithriani L. Antibacterial and Antioxidant Activity of Keladi Tikus Leaves Extract (Typhonium flagelliforme) (Lodd) Blume. Procedia Chem. 2014; 13:209-213.

Ferreira I.C.F.R., Baptista P., Vilas-Boas M., Barros L. Freeradical scavenging capacity and reducing power of wild edible mushrooms from northeast Portugal: Individual cap and stipe activity. Food Chem. 2007;100(4):1511-1516
Flora G., Rani S.M.V. GC-MS analysis of Acanthophora spicifera. Int J Pharma Bio Sci. 2010;4(1):649-653.

Galvez M.A.C. Evaluation of DPPH Free Radical Scavenging Activity and Phytochemical Screening of Selected Folkloric Medicinal Plants in Tinoc, Ifugao, Cordillera Administrative Region, Philippines. Int J Sci Res Publ. 2015;5(12):440-445.

Gil E.S., Couto R.O. Flavonoid electrochemistry: A review on the electroanalytical applications. Brazilian J Pharmacogn. 2013; 23(3): 542-558.

Gopalakrishnan S., Vadivel E. GC-MS analysis of some bioactive constituents of Mussaenda frondosa Linn. Int J Pharma Bio Sci. 2011; 2(1):313-320.

Hemalatha R., Nivetha P., Mohanapriya C., Sharmila G., Muthukumaran C., Gopinath M. Phytochemical composition, GC-MS analysis, in vitro antioxidant and antibacterial potential of clove flower bud (Eugenia caryophyllus) methanolic extract. J Food Sci Technol. 2016; 53(2): 1189-1198

Hussein H.J., Hadi M.Y., Hameed I.H. Study of chemical composition of Foeniculum vulgare using Fourier transform infrared spectrophotometer and gas chromatography - mass spectrometry. J Pharmacogn Phyther. 2016;8(3):60-89.

Kalaiselvan A, Gokulakrishnan K, Anand T. Gas chromatography-Mass spectrum analysis of bioactive components of the ethanol extract of Andrographis paniculata. J Pharm Biomed Sci. 2012; 20(20):1-3.

Kandasamy S., Aradhya S.M. Polyphenolic profile and antioxidant properties of rhizome of commercial banana cultivars grown in India. Food Biosci. 2014;8:22-32.

Khadem S., Marles R.J. Monocyclic phenolic acids; hydroxyand polyhydroxybenzoic acids: Occurrence and recent bioactivity studies. Molecules. 2010;15(11):7985-8005.

Kumar D.G., Rajakumar R. Gas chromatography \& mass spectrometry analysis of bioactive components from the ethanol extract of Avicennia marina leaves. Innovare J Sci. 2016; 4(4):1-4.

Kumar S., Pandey A.K. Chemistry and Biological Activities of Flavonoids: An Overview. Sci World J. 2013; 4(2):32-48.

Kumar S., Prahalathan P. \& Raja B., 2011. Antihypertensive and antioxidant potential of vanillic acid, a phenolic compound in $\mathrm{L}$ NAME-induced hypertensive rats: a dose-dependence study. Redox Report 16, 208-215.

Kumaran A., Karunakaran R.J. In vitro antioxidant activities of methanol extracts of five Phyllanthus species from India. LWT - Food Sci Technol. 2007;40(2):344-352.

Kumari S.T.K., Muthukumarasamy S., Mohan V.R. GC-MS analysis of ethanol extract of Sarcostemma secamone ( L ) Bennet ( Asclepiadaceae ). Sci Res Report. 2012;2(3):187-191.

Leena P., Hukuman NHZ., Jisha M. In vitro antimicrobial efficacy and GC- MS analysis of bioactive components from Lepidagathis keralensis (Acanthaceae). World J Pharm Res. 2016; 5(12):937-948.

Lima G..PP., Vianello F., Corrêa C.R., Campos R.A.D.S., Borguini M.G. Polyphenols in Fruits and Vegetables and Its Effect on Human Health. Food Nutr Sci. 2014; 5(5):1065-1082.

Madhusoodanan PV, Singh N. A New Species of Lepidagathis (Acanthaceae) from South India. Kew Bull.1992; 47: 301-303.

Meenakshi V.K., Gomathy S., Chamundeswari K.P. GC-MS analysis of the simple ascidian Microcosmus exasperatus Heller, 1878. Int J ChemTech Res. 2012; 4(1): 55-62.

Padmanabhan P., Jangle S.N. Evaluation of DPPH radical scavenging activity and reducing power of four selected medicinal plants and their combinations. Int J Pharm Sci Drug Res. 2012;4(2):143-146.

Pavithra G.M., Siddiqua S., Naik A.S., Kekuda P.T.R., Vinayaka K.S. Antioxidant and antimicrobial activity of flowers of Wendlandia thyrsoidea, Olea dioica, Lagerstroemia speciosa and Bombax malabaricum. J Appl Pharm Sci. 2013;3(6):114-120.

Prasad, S. K., Exploration and elucidation of traditional medicinal plants of erstwhile tulunadu and surrounding area of kerala and Karnataka (doctoral thesis), 2012, Kannur University, kerala.660-661. 
Meechai I., Phupong W., Chunglok W., Meepowpan P. Antioxidant properties and phytochemical contents of Garcinia schomburgkiana Pierre. J Appl Pharm Sci. 2016;6(6):102-107.

Shanta M.A., Ahmed T., Uddin M.N., Majumder S., Hossain M.S., Rana M.S. Phytochemical screening and InVitro determination of antioxidant potential of methanolic extract of Streospermum chelonoides. J Appl Pharm Sci. 2013;3(3):117-121.

Shettima A.Y., Karumi Y., Sodipo O.A., Usman H., Tijjani M.A. Gas Chromatography - Mass Spectrometry ( GC-MS ) analysis of bioactive components of ethyl acetate root extract of Guiera senegalensis J.F. Gmel. J Appl Pharm Sci. 2013;3(3):146-150.

Singh P., Singh S., Kapoor I.P.S., Singh G., Isidorov V., Szczepaniak L. Chemical composition and antioxidant activities of essential oil and oleoresins from Curcuma zedoaria rhizomes, part-74. Food Biosci. 2013;3:42-48.

Thambiraj J., Paulsamy S. In vitro antioxidant potential of methanol extract of the medicinal plant, Acacia caesia (L.) Willd. Asian Pac J Trop Biomed. 2012;2(2 SUPPL.):732-736.

Valentova K., Cvak L., Muck A., Ulrichova J., Simanek V. Antioxidant activity of extracts from the leaves of Smallanthus sonchifolius. Eur J Nutr. 2003;42(1):61-66.
Vijayakumar S., Sumathi A. Preliminary phytochemical and GC- MS analysis of bioactive compounds from Moringa concanensis nimmo leaves family: Moringaceae. Int J Recent Adv Multidiscip Res. 2016;3(2):1257-1259.

Yildirim A., Oktay M., Bilaloglu V. The antioxidant activity of the leaves of Cydonia vulgaris. J Med. 2001;31:23-27.

Yu L., Haley S., Perret J., Harris M., Wilson J., Qian M. Free radical scavenging properties of wheat extracts. J Agric Food Chem. 2002;50(6):1619-1624.

\section{How to cite this article:}

Palakkal L, Hukuman NHZ, Mullappally J. Antioxidant activities and chemical composition of various crude extracts of Lepidagathis keralensis. J App Pharm Sci, 2017; 7 (06): 182-189. 